\title{
ESTIMASI NILAI EKONOMI WISATA TAMAN NASIONAL GUNUNG CIREMAI (TNGC)
}

\author{
Asti Istiqomah ${ }^{*}$ )1), Akhmad Fauzi ${ }^{2)}$, Sahat MH Simanjuntak ${ }^{2)}$ \\ 1) Departemen Ekonomi Sumberdaya dan Lingkungan Fakultas Ekonomi dan Manajemen \\ Institut Pertanian Bogor \\ 2) Fakultas Ekonomi dan Manajemen Institut Pertanian Bogor \\ ${ }^{*}$ E)-mail Penulis Korespondensi: asti.istiqomah@gmail.com
}

\begin{abstract}
ABSTRAK
Taman Nasional Gunung Ciremai (TNGC) merupakan kawasan konservasi yang memiliki banyak objek wisata. Objek wisata yang ada di TNGC merupakan wisata berbasis alam yang bisa memberikan tambahan pendapatan bagi masyarakat sekitar hutan sehingga mereka tidak perlu melakukan perambahan ke kawasan konservasi. Dengan demikian, keberadaan wisata ini perlu dipertahankan keberlanjutannya. Namun seringkali ketiadaan berapa besarnya nilai ekonomi dari wisata alam tersebut, menyebabkan adanya kesalahan dalam penentuan kebijakan dalam pemanfaatan kawasan konservasi. Oleh karenanya perlu diestimasi seberapa besar nilai ekonomi dari wisata di TNGC. Metode yang digunakan untuk mengestimasi nilai ekonomi wisata yaitu metode Contingent Choice Model (CCM). Berdasarkan hasil penelitian, rata-rata biaya perjalanan yang dikeluarkan Rp 664.580 per satu kali kunjungan dengan komponen biaya terbesar yaitu biaya transportasi (37\%). Rata-rata besar kesediaan membayar (willingness to pay/WTP) wisatawan TNGC yaitu sebesar Rp 425.919,3, sehingga estimasi nilai ekonomi TNGC yaitu sebesar Rp 638.878.948 per tahun.
\end{abstract}

Kata kunci: Contingent Choice Model (CCM); Nilai Ekonomi Wisata; Taman Nasional Gunung Ciremai (TNGC); Willingness to Pay

\section{PENDAHULUAN}

Indonesia memiliki sumberdaya alam yang sangat besar dan berpotensi memberikan manfaat ekonomi yang besar jika dimanfaatkan dengan tepat. Namun, adanya ketidakjelasan hak kepemilikan (property right) pada beberapa sumberdaya alam mendorong terjadinya inefisiensi dalam penggunaan sumberdaya alam. Kondisi ini juga mendorong terjadinya eksploitasi yang berlebihan (over exploitation) dalam pemanfaatan sumberdaya alam. Upaya mengurangi terjadinya over eksploitasi sumberdaya alam sebenarnya telah lama diperkenalkan melalui konsep pembangunan berkelanjutan (Pagiola et al, 2002). Istilah pembangunan berkelanjutan pertama kali muncul pada tahun 1980 dalam World Conservation Strategy dari the International Union for theConservation of Nature (IUCN).Pembangunan berkelanjutan merupakan pembangunan yang bertujuan memenuhi kebutuhan generasi saat ini tanpa mengurangi kemampuan generasi mendatang untuk memenuhi kebutuhan mereka.

Untuk mencapai pembangunan berkelanjutan, salah satunya yaitu melalui pengelolaan sumberdaya hutan yang berkelanjutan pula. Pengembangan wisata alam atau wisata berbasis ekosistem merupakan salah satu upaya dalam pengelolaan hutan yang berkelanjutan. Dengan dikembangkannya wisata berbasis ekosistem, diharapkan dapat meningkatan kesejahteraan masyarakat tanpa harus mengekstraksi sumberdaya hutan. Pengembangan wisata alam telah banyak dilakukan di Taman nasional, salah satunya yaitu Taman Nasional Gunung Ciremai.Berdasarkan Balai Konservasi Taman 
Nasional Gunung Ciremai (2010),melalui Keputusan Menteri Kehutanan Nomor : SK.424/MENHUT-II/2004, dinyatakan bahwa fungsi Kawasan Hutan Lindung di Kelompok Hutan Gunung Ciremai seluas \pm 15.500 hektar, terletak di Kabupaten Kuningan dan Majalengka, Provinsi Jawa Barat.

Mengacu pada Undang-undang No. 5 Tahun 1990 tentang Konservasi Sumberdaya Alam Hayati dan Ekosistemnya, Taman nasional adalah kawasan pelestarian alam yang mempunyai ekosistem asli, dikelola dengan sistem zonasi yang dimanfaatkan untuk tujuan penelitian, ilmu pengetahuan, pendidikan, menunjang budidaya, pariwisata, dan rekreasi. TNGC telah memiliki 16 objek wisata dimana sebagian besar telah ada sebelum kawasan tersebut ditetapkan sebagai Taman Nasional (Balai Taman Nasional Gunung Ciremai, 2010). TNCG memiliki potensi wisata dan memiliki prospek yang bagus untuk dikembangkan. Pengembangan wisata sangat penting mengingat prospek wisata yang kecenderungan mengalami peningkatan dari waktu ke waktu serta besarnya potensi wisata di TNGC.

Objek wisata di TNGC berbasis ekosistem sehingga perkembangan wisata di TNGC sangat bergantung pada kualitas lingkungan di TNGC. Dengan adanya wisata di kawasan konservasi juga dapat menjadi pendorong bagi masyarakat untuk tidak kembali merambah ke kawasan hutan. Dengan demikian, keberadaan dan keberlanjutan wisata di kawasan konservasi menjadi mutlak dipertahankan. Namun, nilai ekonomi wisata TNGC sampai saat ini belum diketahui berapa. Ketiadaan seberapa besar nilai ekonomi wisata berpotensi menyebabkan adanya kebijakan yang kurang tepat. Oleh karena itu, estimasi nilai ekonomi perlu dilakukan dan akan dijadikan dasar dalam penetapan keputusan oleh pemerintah daerah tentang pengelolaan yang tepat serta berkelanjutan bagi kawasan hutan tersebut khususnya kawasan wisata.

\section{METODE}

\section{Lokasi dan Waktu Penelitian}

Lokasi penelitian yaitu Taman Nasional Gunung Ciremai (TNGC). Dasar penentuan lokasi dilakukan secara purposive (sengaja) dikarenakan TNGC memiliki banyak potensi objek wisata alam. Waktu pengambilan data dilaksanakan pada bulan April-September 2011.

\section{Metode Pengambilan Sampel}

Untuk mengestimasi nilai ekonomi kawasan wisata Taman Nasional Gunung Ciremai, populasi yang digunakan adalah pengunjung kawasan wisata Taman Nasional Gunung Ciremai. Penentuan sampel penelitian dilakukan menggunakan metode nonprobability sampling dengan teknik purposive. Jumlah sampel diambil dengan menggunakan teknik pengambilan contoh sosial ekonomi yang dikembangkan oleh Fauzi (2001) yaitu:

$$
n=\frac{N Z^{2} \times 0,25}{\left(d^{2} \times(N-1)+\left(Z^{2} \times 0,25\right)\right)}
$$

Keterangan :

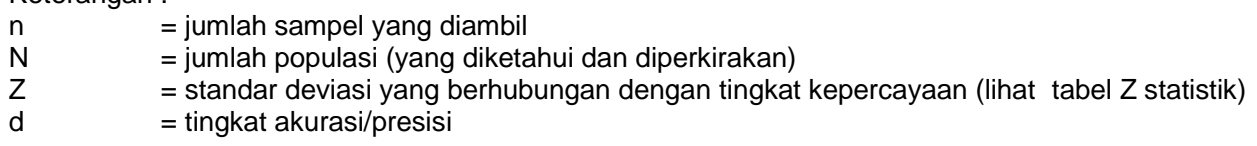

Jumlah wisatawan yang datang ke Taman Nasional Gunung Ciremai adalah 1500 jiwa per tahun (Balai Konservasi Taman Nasional Gunung Ciremai, 2009), sehingga dengan tingkat presisi $10 \%(0,1)$ dan dengan tingkat kepercayaan $95 \%$ maka nilai $Z=$ 1,65 , sehingga akan didapatkan sampel sebesar:

$$
n=\frac{1.500 \times(1,65)^{2} \times 0,25}{\left((0,1)^{2} \times(1.500-1)+\left((1,65)^{2} \times 0,25\right)\right)}=65,15 \approx 65
$$


Dengan demikian, jumlah sampel yang digunakan dalam penelitian ini adalah sebanyak 65 responden.

\section{Contingent Choice Modelling (CCM)}

Dalam penelitian ini model pilihan yang digunakan adalah choice experiment. Teknik ini dilakukan dengan cara meminta kepada responden untuk memilih beberapa alternatif, dimana setiap alternatif merupakan fungsi dari atribut (termasuk harga atau biaya) dan setiap atribut bervariasi. Dalam random utility theory, utilitas seseorang terhadap suatu lokasi atau pengalaman digambarkan oleh fungsi dari utilitas. Fungsi ini kadang-kadang dikenal sebagai fungsi utilitas kondisional tidak langsung:

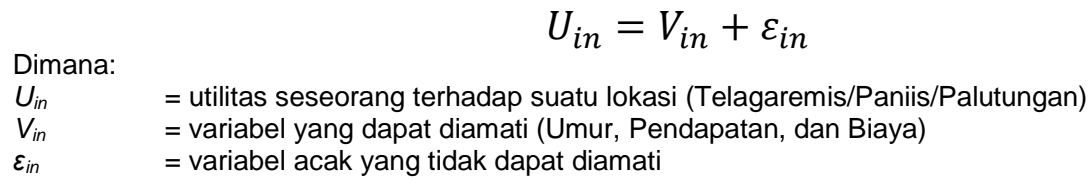

Variabel yang dapat diamati dari utilitas (V) dapat dikembangkan seperti pada persamaan berikut:

$$
V_{\text {in }}=A S C_{i}+\beta_{1} X_{1}+\beta_{2} X_{2}+\beta_{3} X_{3}
$$

Dimana:

$\begin{array}{ll}X_{1} & =\text { umur } \\ X_{2} & =\text { pendapatan } \\ X_{3} & =\text { biaya }\end{array}$

Dalam choice experiment, setiap pengamatan merupakan discrete $0-1$. Hal ini menyatakan bahwa seseorang akan memilih pilihan 0 jika utilitas yang didapat lebih tinggi dari pilihan 1:

$$
U_{0}>U_{1}
$$

Secara sederhana fungsi dari metode yang didasarkan atas utilitas individu ini dapat ditulis sebagai berikut:

$$
P\left(U_{0}>U_{1}\right)=P\left(X_{0} \theta-X_{1} \theta>v_{1}-v_{0}\right)
$$

Keterangan:

$U_{0}>U_{1}=$ seseorang akan memilih pilihan 0 jika utilitas lebih besar daripada pilihan 1

$X \quad=$ vector dari atribut-atribut yang mempengaruhi utilitas

$\theta \quad=$ vektor dari karakteristik yang menggambarkan individu $t$

= variable acak dar iutilitas

Model di atas memprediksi bahwa kemungkinan alternatif yang dipilih adalah pilihan 0 . Selanjutnya nilai Willingness to Pay (WTP) diduga secara tidak langsung menjadi:

$$
\begin{gathered}
\log L=\sum_{i=1}^{N} \sum_{j=1}^{J} y_{i j} \log \left[\frac{\exp \left(V_{i j}\right)}{\sum_{j=1}^{j} \exp \left(V_{i j}\right)}\right] \\
W T P=b_{y}^{-1} \ln \left[\frac{\sum_{i} \exp \left(V_{i}^{1}\right)}{\sum_{i} \exp \left(V_{i}^{0}\right)}\right] \\
W T P=c_{1} \frac{\sum_{i}^{n} \beta_{1} \bar{X}_{1}}{\beta_{1}}+\cdots+c_{n} \frac{\sum_{i}^{n} \beta_{n} \bar{X}_{n}}{\beta_{n}}
\end{gathered}
$$

\section{HASIL DAN PEMBAHASAN}

TNGC memiliki 16 objek wisata dimana semua wisata tersebut berbasis kanalam/ekosistem. Dari seluruh objek wisata tersebut, dipilih 3 lokasi wisata yang dijadikan pilihan dalam mengestimasi Willingness to Pay (WTP) TNGC yang menggambarkan nilai ekonomi wisata di TNGC. Lokasiwisata yang dipilih menjadi sampel yaitu Telagaremis, Paniis dan Palutungan. Telagaremis terletak di Desa Kaduela, 
Kecamatan Pasawahan Kabupaten Kuningan. Objek wisata tersebut memiliki atraksi yaitu sebagai berikut: pemandangan alam, berkemah, jalan-jalan dan sepeda air. Dari sisi kualitas lingkungan, di Telagaremis, kualitas air disana dapat dikatakan bagus dengan indikator tidak berbau dan tidak berwarna. Berdasarkan hasil pengamatan, kualitas udara dan vegetasi secara umum juga masih bagus. Lokasi objek wisata ini juga memiliki akesisibilitas yang cukup baik. Aksesibilitas Telagaremis yaitu $\pm 15 \mathrm{~km}$ dari kantor Seksi PTN Wilayah I Kuningan. Sarana prasarana yang terdapat di objek wisata tersebut yaitu pos tiket, pos jaga, papan petunjuk, shelter, mushalla, MCK, warung, dan panggung. Besarnya tiket masuk yaitu sebesar Rp 7.500 per individu.

Sementara, objek wisata Palutungan berlokasi di Desa Cisantana, Kecamatan Cigugur Kabupaten Kuningan. Atraksi yang ada yaitu perkemahan, wisata air terjun, pemandangan alam, dan outbond. Kualitas air disana sangat bagus (tidak berwarna dan tidak berbau). Kualitas udara dan vegetasi juga masih bagus. Aksesibilitas menuju lokasi wisata juga cukup baik. dari Palutungan yaitu $\pm 14 \mathrm{~km}$ dari kantor Balai TNGC atau sekitar \pm 40 menit dengan menggunakan kendaraan. Sarana dan prasarana yang ada di objek wisata tersebut yaitu pos tiket, shelter, papan petunjuk, papan larangan, MCK, mushalla, dan warung. Besarnya tiket yang dikenakan kepada pengunjung adalah sebesar Rp 6.000 .

Selanjutnya, objek wisata Paniis mengenakan tiket masuk kepada pengunjung sebesar Rp 5.000, yakni paling murah dibandingkan dengan lokasi wisata lainnya yang berada di TNGC. Lokasi objek wisata tersebut yaitu berada di Desa Paniis, Kecamatan Pasawahan Kabupaten Kuningan. Atraksi yang ada di objek wisata ini terbatas yaitu hanya berkemah dan sumber mata air. Kualitas lingkungan khususnya air masih sangat bagus sehingga air Paniis ini juga dimanfaatkan oleh PDAM Kota Cirebon. Kualitas udara dan vegetasi juga masih bagus. Aksesibilitas lebih mudah dijangkau yaitu $\pm 10 \mathrm{~km}$ dari kantor Balai TNGC atau sekitar \pm 30 menit dengan menggunakan kendaraan. Sarana prasarana yang ada yaitu pos tiket, pos jaga, shelter, papan larangan, MCK, mushalla, dan warung.

\section{Karakteristik Responden Pengunjung Kawasan Wisata Taman Nasional Gunung Ciremai (TNGC)}

Sebagian besar dari responden yaitu berjenis kelamin laki-laki yaitu sebesar 82 persen. Sebaran jenis kelamin yang tidak proporsional tidak menjadi suatu hal yang masalah dikarenakan pengunjung kawasan wisata TNGC biasanya berkelompok yang merupakan suatu keluarga.Pengunjung kawasan wisata TNGC Kuningan mayoritas merupakan pendatang dari berbagai macam daerah. Hanya sebesar 12 persen dari pengunjung kawasan wisata TNGC yang merupakan masyarakat asli atau berasal dari Kabupaten Kuningan.

Pengunjung kawasan wisata TNGC terbesar yaitu berasal dari Kabupaten Sumedang. Lokasi yang dekat diduga menjadi alasan tingginya jumlah pengunjung yang berasal dari Sumedang. Selain pengunjung yang berasal dari Kabupaten Sumedang, pengunjung kawasan wisata TNGC juga banyak berasal dari Kabupaten/Kota Tasikmalaya dan Kabupaten Karawang. Pengunjung asal Kabupaten Bekasi, DKI Jakarta, dan Kabupaten Garut juga cukup banyak, sementara sisanya berasal dari daerah lain. Bahkan terdapat juga pengunjung yang berasal dari Kabupaten Cianjur dan Sukabumi yang tentunya memiliki lokasi yang cukup jauh dengan kawasan wisata TNGC. Namun, sebagian besar dari pengunjung mendapatkan informasi mengenai kawasan wisata TNGC yaitu berasal dari keluarganya yang berasal dari Kabupaten Kuningan.

Sebagian besar pendidikan terakhir dari pengunjung kawasan wisata TNGC yaitu lulusan SMA sebesar 52,24 persen. Pengunjung yang pendidikan terakhirnya S1 juga cukup besar yaitu sebesar 25,37 persen sedangkan sisanya berpendidikan akhir D3 dan D1. Hasil juga menunjukkan bahwa jenis pekerjaan pengunjung kawasan wisata TNGC terbagi ke dalam tiga jenis yaitu swasta, wiraswasta, dan PNS. Sebagian besar dari pengunjung kawasan wisata TNGC adalah pegawai swasta yaitu sebesar 40,30 persen. 
Sisanya adalah wiraswasta dan PNS dimana pengunjung yang PNS memiliki jumlah yang paling sedikit.

\section{Estimasi Nilai Ekonomi Kawasan Wisata TNGC}

Perhitungan nilai WTP yaitu menggunakan CCM dengan melihat hasil persamaan logistik binomial. Berdasarkan hasil survey di tiga lokasi wisata di TNGC, diperoleh rincian biaya yang dikeluarkan oleh pengunjung wisata tersebut. Rincian biaya yang dikeluarkan oleh pengunjung kawasan wisata TNGC dapat dilihat pada Tabel 1.

Tabel 1 Biaya Berkunjung Ke Kawasan Wisata TNGC (Rp/Kali Kunjungan)

\begin{tabular}{clrc}
\hline No & Jenis Biaya & Biaya (Rp) & Proporsi (\%) \\
\hline 1 & Biaya Transportasi & 248.358 & 37 \\
2 & Biaya Akomodasi & 200.000 & 30 \\
3 & Biaya Konsumsi & 175.864 & 26 \\
4 & Biaya Dokumentasi & 34.022 & 5 \\
5 & Tiket & 6.336 & 1 \\
\hline & Jumlah & $\mathbf{6 6 4 . 5 8 0}$ & $\mathbf{1 0 0}$ \\
\hline
\end{tabular}

Sumber: Data primer diolah, 2011

Sementara itu, nilai ekonomi kawasan wisata TNGC dihitung dari hasil regresi antara lokasi wisata dengan variabel independen yang sudah ditentukan dan diduga berpengaruh terhadap pilihan untuk mengunjungi lokasi wisata. Persamaan regresi yang dipakai yaitu persamaan logistik binomial dimana variabel dependennya berupa pilihan lokasi wisata yaitu Telagaremis, Paniis, dan Palutungan. Sedangkan variabel independen yang dipilih adalah biaya, umur, dan pendapatan. Adapun persamaan dari regresi binomial logistik dari lokasi Telagaremis yaitu sebagai berikut:

$$
Y_{T R}=7,54+0,967 U M+2,513 P D T+2,104 B P+\varepsilon
$$

Dimana:

$$
\begin{array}{ll}
Y_{T R} & =\text { pilihan terhadap Telagaremis }(1=\text { ya, } 0=\text { tidak }) \\
U M & =\text { umur (tahun) } \\
P D T & =\text { pendapatan }(\text { Rp/bulan }) \\
B P & =\text { biaya }(\text { Rp } / \text { kunjungan })
\end{array}
$$

Hasil regresi logistik binomial menunjukkan bahwa secara umum pemilihan lokasi wisata dipengaruhi oleh biaya dan pendapatan. Pilihan wisatawan terhadap TNGC khususnya Telagaremis dipengaruhi oleh biaya dan pendapatan. Rata-rata biaya yang dikeluarkan wisatawan yang memilih lokasi ini adalah Rp 209.275 dengan rata-rata pendapatan wisatawan yaitu Rp 2.448.276. Nilai koefisien dari hasil analisis regresi menunjukkan bahwa jika pendapatan naik satu rupiah maka peluang (kemungkinan) wisatawan untuk memilih Telagaremis akan menurun 0,08 kali. Hal tersebut mengindikasikan bahwa Telagaremis ini merupakan lokasi wisata yang tidak menjadi andalan bagi wisatawan. Nilai odds ratio yang diperoleh adalah 8,2 yang berarti bahwa jika biaya naik sebesar satu rupiah maka peluang (kemungkinan) wisatawan untuk memilih Telagaremis meningkat 8,2 kali. Kondisi ini menunjukkan bahwa sebagian besar wisatawan masih beranggapan bahwa biaya yang besar berkorelasi positif dengan fasilitas maupun kualitas lingkungan dari lokasi wisata. Selain itu, Telagaremis juga ternyata bukan lokasi wisata yang menjadi utama. Sementara hasil regresi logistik binomial untuk lokasi Paniis yakni sebagai berikut.

Dimana

$$
Y_{P a}=7,54+0,967 U M+2,513 P D T+2,104 B P+\varepsilon
$$

$Y_{p a} \quad=$ pilihan terhadap Paniis $(1=$ ya, $0=$ tidak $)$

$U M \quad=$ umur (tahun) 


$$
\begin{array}{ll}
P D T & =\text { pendapatan }(\mathrm{Rp} / \text { bulan }) \\
B P & =\text { biaya }(\text { Rp/kunjungan })
\end{array}
$$

Sama halnya dengan Telagaremis, pilihan lokasi Paniis juga dipengaruhi oleh biaya dan pendapatan. Dari sisi odds ratio, hasil menunjukkan bahwa jika biaya naik satu rupiah maka peluang (kemungkinan) wisatawan untuk memilih Paniis akan menurun 0,24 kali. Hal ini menunjukkan bahwa biaya saat ini untuk mengunjungi Paniis sudah cukup tinggi bagi wisatawan sehingga apabila terjadi kenaikan maka wisatawan akan lebih memilih lokasi wisata lain. Kondisi tersebut juga sejalan dengan hasil pengamatan di lapang bahwa lokasi wisata Paniis ini masih sangat minim fasilitas. Nilai odds ratio yang diperoleh adalah 8,2 yang berarti bahwa jika biaya naik sebesar satu rupiah maka peluang (kemungkinan) wisatawan untuk memilih Paniis akan meningkat 9,63 kali, Kondisi ini menggambarkan bahwa pendapatan wisatawan yang memilih lokasi wisata Paniis masih relatif lebih kecil dibandingkan wisatawan lokasi wisata lain.Sementara untuk lokasi wisata Palutungan, model yang diperoleh tidak signifikan sehingga tidak dapat menggambarkan kenyataan yang ada. Berikut hasil analisis regresi logistik binomial alternatif pilihan wisatawan di TNGC secara rinci.

\begin{tabular}{|c|c|c|c|c|c|c|c|c|c|}
\hline \multirow[b]{2}{*}{ Atribut } & \multicolumn{3}{|c|}{ Telagaremis* } & \multicolumn{3}{|c|}{ Paniis ${ }^{\star *}$} & \multicolumn{3}{|c|}{ Palutungan ${ }^{\star \star *}$} \\
\hline & Coef. & $\mathbf{P}$ & $\begin{array}{l}\text { Odds } \\
\text { Ratio }\end{array}$ & Coef. & $\mathbf{P}$ & $\begin{array}{l}\text { Odds } \\
\text { Ratio }\end{array}$ & Coef. & $\mathbf{P}$ & $\begin{array}{l}\text { Odds } \\
\text { Ratio }\end{array}$ \\
\hline Intercept & 7,543 & 0,616 & & $-12,868$ & 0,468 & & $-5,664$ & 0,693 & \\
\hline Umur & 0,967 & 0,607 & 2,63 & $-1,205$ & 0,518 & 0,3 & $-0,549$ & 0,737 & 0,58 \\
\hline Pendapatan & $-2,513$ & 0,033 & 0,08 & 2,265 & 0,094 & 9,63 & 1,119 & 0,297 & 3,06 \\
\hline Biaya & 2,104 & 0,008 & 8,2 & $-1,436$ & 0,043 & 0,24 & $-0,767$ & 0,192 & 0,46 \\
\hline
\end{tabular}

Table 2 Hasil Regresi Logistik Binomial Alternatif Pilihan Wisatawan

Sumber: Data primer diolah, 2011

Keterangan:

* = signifikan pada taraf nyata 5\%

* = signifikan pada taraf nyata $15 \%$

${ }^{* * *}=$ tidak signifikan

Dari persamaan di atas, diperoleh nilai WTP wisatawan untuk lokasi wisata Telagaremis yaitu sebesar Rp 346.139,3. Untuk lokasi wisata Paniis diperoleh WTP sebesar Rp 505.699,3. WTP untuk lokasi wisata Palutungan yaitu Rp 455.111,7. Hal ini menunjukkan bahwa tingkat kepuasan dan persepsi wisatawan terhadap lokasi Telagaremis adalah paling tinggi. Namun, dikarenakan model untuk lokasi wisata Palutungan secara statistik tidak bisa menggambarkan kenyataan yang ada (taraf nyata lebih dari 30 persen), maka untuk model regresi logistik binomial lokasi wisata Palutungan diabaikan. Sehingga rata-rata WTP wisatawan TNGC yaitu sebesar Rp 425.919,3. Nilai ekonomi TNGC diperoleh dari hasil perkalian nilai WTP rata-rata wisatawan dengan jumlah wisatawan yang datang ke TNGC yaitu sebanyak 1500 jiwa, maka nilai ekonomi kawasan wisata Taman Nasional Gunung Ciremai (TNGC) berdasarkan Contingent Choice Modelling (CCM) yaitu sebesar Rp 638.878.948 per tahun.

\section{SIMPULAN}

Pilihan wisatawan terhadap TNGC dipengaruhi oleh biaya dan pendapatan. Ratarata biaya perjalanan wisatawan per satu kali kunjungan yaitu adalah Rp 664.580. WTP wisatawan untuk lokasi wisata Telagaremis yaitu sebesar $R p$ 346.139,3. Untuk lokasi wisata Paniis diperoleh WTP sebesar Rp 505.699,3. WTP untuk lokasi wisata Palutungan yaitu Rp 455.111,7. Hal ini menunjukkan bahwa tingkat kepuasan dan persepsi wisatawan terhadap lokasi Paniis adalah paling tinggi. Paniis menjadi pilihan tertinggi 
karena biaya yang relatif lebih murah dan kualitas lingkungan terutama air masih sangat bagus. Nilai ekonomi kawasan wisata Taman Nasional Gunung Ciremai (TNGC) berdasarkan Contingent Choice Modelling (CCM) yaitu sebesar Rp 638.878.948 per tahun.

\section{DAFTAR PUSTAKA}

Balai Taman Nasional Gunung Ciremai. 2010. Mount Ciremai national Park, Natural Tourism Location.

Balai Taman Nasional Gunung Ciremai. 2010. Laporan Tahunan Tahun 2009

Pramono, Bambang T\& Kunarso A. 2010. Valuasi Ekonomi Taman Wisata Alam Punti Kayu Palembang. Jurnal Penelitian Hutan dan Konservasi Alam Vol. VII No.1 : 1323.

Fauzi, A. 2001. Prinsip-Prinsip Penelitian Sosial Ekonomi: Panduan Singkat. Jurusan Sosial Ekonomi Perikanan dan Kelautan. IPB.

Fauzi, A. 2006. Ekonomi Sumberdaya Alam dan Lingkungan. Teori dan Aplikasi. PT. Gramedia Pustaka Utama: Jakarta

Mogas, Joan, Pere R., dan Jeff B. 2006. A Comparison of Contingent Valuation and Choice Modelling with Second Order Interactions.

Nam, Pham Khanh dan Son, Tran Vo Hung. 2010. Household Demand For Improved Water Services in Ho Chi Minh City. Economy and Environment Program For Southeast Asia (EEPSEA).

Pagiola, Stefano., Joshua B., dan Nathasa L.M. 2002. Selling Forest Environmental Services. Market-based Mechanism for Conservation and Development.London (UK). Earthscan Publicatons Ltd.

Pemerintah Kabupaten Kuningan. 2010. Data Kehutanan dalam www.kuningankab.go.id diakses pada tanggal 2 Oktober 2010.

Pemerintah Provinsi Jawa Barat. 2010. Profil Daerah dalamhttp://www.jabarprov.go.id diakses pada tanggal 31 Oktober 2010.

Philcox, N. 2006. An Application of Contingent Choice Modelling to Assess Environmental Management Options In The Shrimp-Mangrove System In The Indian Sundarbans. Simon Fraser University.

Putrantomo, F. 2010. Aplikasi Contingent Choice Modelling (CCM) Dalam Valuasi Ekonomi Terumbu Karang Taman Nasional Karimunjawa. Tesis. Institut Pertanian Bogor. Bogor

Shone, Bryan M. dan Jill L. Caviglia-Harris. 2005. Quantifying and Comparing The Value of Non-Timber Forest Products in The Amazon. Jurnal Ecologycal Economics 58 (2006) 249-267.

The, Bui Dung. 2010. The On-Site Costs of Soil Erosion and Choice of Land Use Systems By Upland Farmers in Central Vietnam. Economy and Environment Program For Southeast Asia (EEPSEA).

Wardiyanta. 2006. Metode Penelitian Pariwisata. Penerbit Andi: Yogyakarta

Yoeti OA. 2008. Ekonomi Pariwisata. PT. Kompas Media Nusantara: Jakarta 